\title{
Community Perception of The Conversion of Forest Land Into Building Land in Bangsar South Malaysia
}

\author{
*Revi Annisa ${ }^{1}$ and Abishaah BT Akhubar Ali $^{2}$ \\ 1) Graduate Student of Geography Education, Universitas Negeri Padang, Indonesia \\ e-mail: reviannisa2017@gmail.com \\ 2) Student of Geography, Malaya University, Malaysia \\ e-mail: abirah19feb@gmail.com
}

*Corresponding Author, Received: September 14, 2018, Revised: October 21, 2018, Accepted: December 05, 2018

This is an open acces article distributed under the Creative Commons 4.0 Attribution License, wich permits unrestricted use, Distribution, and reproduction in any medium provided the original work is properly cited @2017 by author and Universitas Negeri Padang

\begin{abstract}
The conversion of land function in Bangsar South Malaysia occurred due to the development of forest land use into building land. The conversion of this land has not been fully carried out and is still under construction. Some Malaysians reject the land conversion function by making a petition to refuse land conversion activities to be carried out in Bangsar South Malaysia. The purpose of this study was to find out the perception of Malaysian people about the conversion of forest land into building land in Bangsar South Malaysia. The collection data method used in this research is the interview technique. The results of this study indicate that the Malaysian public's perception of the conversion of forest land to building land in Bangsar South Malaysia showed disagreement with some of the reasons they put forward. The reasons for the refusal by the Malaysians include damaging to the forest areas, reducing buffer zones, causing the possibility of flooding, increasing environmental temperature, causing a lack of absorption of groundwater and reducing fauna habitat in the forest which causes the fauna to move towards residential areas and disturb the security of the surrounding population..
\end{abstract}

Keywords: Land Conversion, Bangsar South, Malaysia

\section{Introduction}

The increasing demand for land which is used for development as a result of land use that continues to move towards forest areas in Bangsar South Malaysia. As a result, a lot of green lands is converted into a building that is physically built as it is built into a residential area or as a fulfilment of the need for infrastructure and so on. The need for building land is a need that must be met including the increase in the construction of new infrastructure to support activities and services in daily activities (Hermon, 2016a; Hermon, 2017a). The conversion of this land function gave rise to various perceptions among Malaysian society. This is due to the existence of other development plans that require wider land and not only for the benefit of residential areas, but also for the interests of entrepreneurs. In addition, the negative impacts on the environment resulting from the conversion of land also became a polemic among the people so that the people petitioned for the refusal of land conversion in Bangsar South Malaysia. Therefore, the conversion of the land function needs to be considered and examined regarding the perception of the people in the vicinity of the Bangsar South area. This is useful for the future input for the Malaysian government in decision making regarding the conversion of land carried out in the Bangsar South area. So that this research is carried out with the title of people's perception of the conversion of forest land into building land in Bangsar South Malaysia. 


\section{Method}

This type of this research is a qualitative descriptive study. The data collection technique of this research is interview techniques. Research data were collected from the results of the interview with informants in the form of primary data or taken directly from the field. The research instrument was the researcher himself and the voice recorder and a set of questions about the perception of the Malaysian people about the conversion of forest land into building land in Bangsar South Malaysia.

\section{Results and Discussion}

According to Umar et al., (2016); Hermon (2010a); Hermon (2012a); Hermon (2015), that human life cannot be separated from land use. The conversion of land function has the meaning of changing the function of the land that has been planned, whether some part or all part of the land area from its original function to another function and usually converted into the development sector. The conversion of land functions can also be interpreted as the initial land use change that has been converted to other land uses that have been planned by certain parties by the conversion of the land function.

The conversion of the land function is no longer a strange thing to hear (Hermon, 2009; Hermon, 2010b). This phenomenon has occurred in many areas that are under construction (Hermon, 2012b; Hermon, 2014a; Hermon, 2014b). Along with its development, the development in almost all cities also experienced physical development as in other large public cities, that is to say more built facilities and infrastructure supported by the increasing capacity and welfare of the community, the physical development of the city also continued to accelerate rapidly (Hermon, 2016a; Hermon, 2016b). But on the other hand, this development has a negative impact on vegetated land or green space because more and more of the conversion from green areas into built areas causing more limited land for green space. The symptoms of this development are seen as the initial degradation of the decreasing availability of green open spaces (Hermon, 2001; Hermon and Khairani, 2009; Hermon, 2011; Hermon, 2012c). Many green lands are converted into shops, settlements, industries, roads and other infrastructure. In the end, there will be an imbalance between the extent of the land being built and the small amount of land for urban forests. The existence of forests as green space is needed in the arrangement of integrated areas in the region to compensate for building density. The various forms of green space activities are generally as shade from the warming of the surrounding environment and as a place for people to socialize and interact with nature. Fulfilment of green areas in urban areas is an initial effort to foster awareness of environmental media in terms of the tendency to decrease the availability of clean and healthy air due to natural degradation. According to the Intergovernmental Panel on Climate Change (2008); Hermon et al., (2017); Hermon et al., (2018a); Hermon et al., (2018b); Hermon et al., (2018c), that global warming (global warming) has now become a serious phenomenon and has a major influence on human life today, not only for the ecological environment but also for the social and cultural environment. Basically, global warming is an increase in global temperature from year to year. One of the causes is the greenhouse effect (Kristian and Oktorie, 2018). There are several factors that led to the conversion of forest land. Important factors that cause land use transfer are :

\section{Increasing population}

As time goes by, the population increases. The rapid increase in population certainly results in more land or the amount of land needed.

2. Improving the standard of living of the community

Improving living standards can also be said to be one of the driving factors (causes) of land use change activities, as seen from land demand due to the increasing intensity of community activities such as shopping centres, highways, tourist attractions (recreation areas), sports fields, and places - other public places.

3. The need for infrastructure development

The need for existing infrastructure makes the possibility of the conversion of forest land into building land. The needs related to this infrastructure are settlements, roads, malls and several other buildings that support business and daily activities. However, by putting aside environmental problems that might occur and the impact on local communities around the area that are subject to the conversion of land use. 
The conversion of forest land into a constructed building that has a different function from other than green land cannot be dealt with during development for the construction of the area still occurs (Oktorie, 2017). However, there are a number of strategies to anticipate and overcome the problems that arise due to the conversion of land functions before over-functioning occurs. There are the coping strategies:

1. Minimizing opportunities for land use change by reducing the intensity of factors that can encourage the change of land use.

2. Controlling land conversion activities in order to suppress potential negative impacts.

3. Overcoming or neutralizing the negative impacts of land conversion.

4. Minimizing the chance of land conversion by reducing the intensity of factors that can encourage land conversion that can be realized with the following efforts:

a. Suppress the rate of population growth.

b. Relocation or resettlement of residents to reduce pressure on land.

c. Developing progressive taxes on non-green or non-forest land to reduce excessive and inefficient land demand.

d. Applying the principle of land saving in developing every land use.

The conversion of forest land in Bangsar South creates a perception in Malaysian society. Even the people petitioned the land conversion function, they refused. The reason for the refusal by the Malaysians of the conversion of forest land to building land includes:

\section{Damage to the forest area}

The conversion of forest land to building land carried out in Bangsar South caused damage to the forest area with reduced the flora found there which would also have a direct impact on the fauna contained there. The biodiversity contained in the forest will also be greatly reduced and the forest that was originally in good condition will be disrupted and damaged due to changes in land use into building land. Natural forest areas as well as being a place to live or habitat for existing forest fauna becomes narrow and causes existing fauna to lose their homes. In addition, forests that are forcibly cleared will certainly suffer damage and also burning some of the remaining results of clearing will also cause damage to the land of the forest area that has undergone into land conversion.

\section{Reduced buffer zone}

Forests as buffer zones and protected areas and green open spaces are reduced. So that the forest as a life buffer has decreased its role and experienced the decreasing area. So that the balance of the previous environment will be disturbed as well. The buffer zone which is one of the important things in maintaining the balance of the environment will be greatly reduced if there is a large conversion of forest land into building land.

3. Causes the possibility of flooding and causes a lack of absorption of groundwater

Flooding can occur if running water and water descending from the sky due to heavy rain floats widely on the ground. The conversion of forest land will cause a greater possibility of flooding. This is related to the increasing run-off that will occur due to the reducing of land cover in the form of forests that can reduce the possibility of flooding. The lack of vegetation or forest vegetation causes the decreasing of water to be absorbed into the soil so that water builds up and can increase the possibility of flooding.

\section{Increased ambient temperature}

Forest as an $\mathrm{O}_{2}$ producer can cool the ambient temperature. Besides that, the photosynthetic activities of plants contained in the forest are able to absorb $\mathrm{CO}_{2}$ which is a gas which causes the increasing of the temperature in the environment. If there is a conversion of forest land into building land, then the number of plants in the forest will be reduced, causing $\mathrm{O}_{2}$ production to decline and conversely the presence of $\mathrm{CO}_{2}$ increases from the previous amount. This certainly causes the environment temperature to tend to increase and cause public discomfort.

\section{Reduced habitat for forest fauna}

The conversion of forest land into building land causes the forest to narrow as a habitat for several faunae that lives in it. So that causes the fauna to move to find a new place to live. The fauna also disturbs the 
security of the surrounding residents due to their movement to find a new place to live in residential areas. Forest fauna which tends to be partly wild makes the surrounding community feel threatened.

\section{Conclusion}

The conversion of land function means that the change in the function of the land that has been planned, either some part or all part of the land area from the original function becomes another function and usually converted to the development sector. The conversion of land function can also be interpreted as the initial land use change that has been converted to other land uses that have been planned by certain parties with the conversion of the land function. There are several factors that led to the conversion of forest land. Important factors that cause land use transfer are: increasing population; improving the standard of living of the community, the need for infrastructure development; efforts that can be made in reducing the possibility of the conversion of forest land into building land and the reason for the refusal by the Malaysians of the conversion of forest land to building land includes damage to forest area, reduced buffer zone, causes the possibility of flooding and causes a lack of absorption of groundwater, increased ambient temperature, reduced habitat for forest fauna.

\section{References}

Fischer, G. 2000. Journal of Environment and Planning : IIASA's Land Use Change Project Examines Land Issues in China. University of Hong kong. Vol. 74, Issue 1.

Hamidah, N., G. Tatau and S, Mahdi. 2015. Jurnal Perspektif Arsitektur: Pengelolaan Kawasan Ruang Hijau di DAS Kahayan Kota Palangkaraya. Universitas Palangkaraya.

Hermon, D. 2001. Studi Kontribusi Penggunaan Lahan dan Vegetasi Terhadap Karakteristik Epipedon. Tesis Magister. Program Pascasarjana Universitas Andalas Padang.

Hermon, D., Khairani., Daswirman., S. Karim., Dasrizal., and Triyatno. 2008. Metode dan Teknik Penelitian Geografi Tanah: Aplikasi Instrumen dan Acuan Penelitian Geografi Fisik. Yayasan Jihadul Khair Center.

Hermon, D and Khairani. 2009. Geografi Tanah: Suatu Tinjauan Teoritis, Metodologis, dan Aplikasi Proposal Penelitian. Yayasan Jihadul Khair Center.

Hermon, D. 2009. Dinamika Permukiman dan Arahan Kebijakan Pengembangan Permukiman pada Kawasan Rawan Longsor di Kota Padang. Disertasi. IPB Bogor.

Hermon, D. 2010a. Geografi Lingkungan: Perubahan Lingkungan Global. UNP Press.

Hermon, D. 2010b. Arahan Kebijakan Pengembangan Permukiman pada Kawasan Rawan Longsor di Kota Padang. Jurnal SKALA. Vol. 1.

Hermon, D. 2011. Studi Karakteristik Epipedon berdasarkan Penggunaan Lahan di Kecamatan X Koto Kabupaten Tanah Datar. Universitas Andalas.

Hermon, D. 2012a. Mitigasi Bencana Hidrometeorlogi: Banjir, Longsor, Degradasi Lahan, Ekologi, Kekeringan, dan Puting Beliung. UNP Press. Padang.

Hermon, D. 2012b. Dinamika Cadangan Karbon Akibat Perubahan Tutupan Lahan Permukiman di Kota Padang Sumatera Barat. Forum Geografi: Indonesian Juornal of Spatial and Regional Analysis. Volume 26. Issue 1. p: 45-52. Uniiversitas Muhammadiyah Surakarta.

Hermon, D. 2012c. Analisis Erodibilitas Tanah dengan Metode Bouyoucos untuk Arahan Pertanian Konservasi Ideal dalam Pembangunan Berkelanjutan. Jurnal Pelangi. Vol. 2 Issue. 2.

Hermon, Dedi. 2014a. Arahan Mitigasi Bencana Longsor Kawasan Gunung Padang Kota Padang Sumatera Barat. Jurnal Geografi. Volume 9.

Hermon, D. 2014b. Impacts of Land Cover Change on Climate Trend in Padang Indonesia. Indonesian Journal of Geography. Volume 46. Issue 2. p: 138-142. Fakultas Geografi Universitas Gajah Mada.

Hermon, D. 2015. Geografi Bencana Alam. Jakarta: PT RajaGrafindo Persada. 
Hermon, D. 2016a. Mitigasi Perubahan Iklim. Rajawali Pers (Radjagrafindo).

Hermon, D. 2016b. Estimate of Changes in Carbon Stocks Based on Land Cover Changes in the Leuser Ecosystem Area (LEA) Indonesia. Forum Geografi. Volume 29. Issue 2. p: 188-196.

Hermon, D. 2016c. The Change of Carbon Stocks and CO2 Emission as the Result of Land Cover Change for Tin Mining and Settlement in Belitung Island Indonesia.Journal of Geography and Earth Science. Volume 4. Issue 1. p: 17-30.

Hermon, D. 2017. Climate Change Mitigation. Rajawali Pers (Radjagrafindo).

Hermon, D., P. Iskarni., O. Oktorie and R. Wilis. 2017. The Model of Land Cover Change into Settlement Area and Tin Mining and its Affecting Factors in Belitung Island, Indonesia. Journal of Environment and Earth Science. Volume 7 No. 6. p: 32-39. IISTE.

Hermon, D., Ganefri., A. Putra and O. Oktorie. 2018a. The Model of Mangrove Land Cover Change for the Estimation of Blue Carbon Stock Change in Belitung Island-Indonesia. International Journal of Applied Environmental Sciences. Volume 13. Issue 2. p: 191-202. Research India Publication.

Hermon, D., Y. Suasti., Ernawati., Afdhal., and H. Edial. 2018b. Geografi: Geografi untuk SMU. Jurusan Geografi Universitas Negeri Padang.

Hermon, D., A. Putra and O. Oktorie. 2018c. Suitability Evaluation of Space Utilization Based on Enviromental Sustainability at The Coastal Area of Bungus Bay in Padang City, Indonesia. International Journal of GEOMATE. Volume 14. Issue 41. p: 193-202. Geomate International Society.

Huang, B.O and X. Chenglin. 2009. Journal of Environment and Planning : Land Use Change Modelling Using Unbalanced Support Vector Machine. University of Hong kong. Vol. 36, 3 : pp. 398 - 416.

Kristian, A and O. Oktorie. 2018. Study of Coastal Mangrove Conservation in the World. Sumatra Journal of Disaster, Geography and Geography Education. Volume 2. Issue 1. p: 49-52

Macklin, G and Choulthard, T. 2001. Journal of Quaternary Science : How Sensitive are River Systems to Climate and Land Use Change? A Model of Land Use Change. University of Wales.

Oktorie, O. 2017. A Study of Landslide Areas Mitigation and Adaptation in Palupuah Subdistrict, Agam Regency, West Sumatra Province, Indonesia. Sumatra Journal of Disaster, Geography and Geography Education. Volume 1. Issue. 1. p: 43-49. Master Program of Geography Education.

Palchoudhuri, Y., R. P. Sarathi and S. Vijay. 2015. Journal of Land and Rural Studies : A New SocioEconomic Index for Modelling Land Use and Land Cover Change. University of Hyderabad. Vol. 3, $1:$ pp. $1-28$.

Palmer, J. 2014. Journal of Environment and Planning: Biofuels and The Politics of Land Use Change: Tracing The Interactions of Discourse in Place Of European Policy Making. University of Bristol. Vol. 46, 2 : pp. $337-352$.

Robinson, D and M. Emilio. 2004. Journal of Environment and Planning : Colonist Household Decisionmaking and Land Use Change in the Amazon Rainforest : An- Agen Based Simulation. University of Central Florida. Vol. 31. Issue 5.

Umar, I., Widiatmaka., B. Pramudya. And B. Barus. 2016. Prioritas Pengembangan Kawasan Permukiman pada Wilayah Rawan Banjir di Kota Padang, Provinsi Sumatera Barat. Institut Pertanian Bogor. Vol. 19 No. 1 April $2017: 83$ - 94. 